\title{
Tephrosia sinapou extract reduces inflammatory leukocyte recruitment in mice: effect on oxidative stress, nitric oxide and cytokine production
}

\author{
Renata M. Martinez, ${ }^{1 \#}$ Ana C. Zarpelon, ${ }^{2 \#}$ Vanessa V. M. \\ Zimermann, ${ }^{1}$ Sandra R. Georgetti, ${ }^{1}$ Marcela M. Baracat, ${ }^{1}$ Maria \\ J. V. Fonseca, ${ }^{3}$ Fabiana T. M. C. Vicentini, ${ }^{3}$ Isabel C. Moreira, ${ }^{4}$ \\ Cesar C. Andrei, ${ }^{5}$ Waldiceu A. Verri, Jr., ${ }^{*, 2}$ Rubia Casagrande ${ }^{*, 1}$
}

\author{
${ }^{1}$ Departamento de Ciências Farmacêuticas, Centro de Ciências da Saúde, \\ Universidade Estadual de Londrina, Brazil, \\ ${ }^{2}$ Departamento de Patologia, Centro de Ciências Biológicas, Universidade Estadual \\ de Londrina, Parana, Brazil, \\ ${ }^{3}$ Departamento de Ciências Farmacêuticas, Faculdade de Ciências Farmacêuticas \\ de Ribeirão Preto, Brazil, \\ ${ }^{4}$ Universidade Tecnológica Federal do Paraná, Brazil, \\ ${ }^{5}$ Laboratório de Pesquisa em Moléculas Bioativas, Departamento de Química, \\ Universidade Estadual de Londrina, Brazil.
}

\begin{abstract}
Tephrosia toxicaria (Sw.) Pers., which is currently known as T. sinapou (Buc'hoz) A. Chev., Fabaceae, is a source of compounds such as flavonoids, however, few studies addressed the anti-inflammatory and antioxidant effects of T. sinapou. Therefore, we evaluated the antioxidant mechanisms of the $T$. sinapou ethyl acetate extract in vitro, and whether the extract affects leukocyte recruitment in four models of inflammation and the involvement of nitric oxide and cytokines in its mechanism. In vitro, it was observed that the extract presented hydrogen donating ability to 2,2diphenyl-1-picryl-hydrazyl radical (DPPH'), 2,2'-azino-di-(3-ethylbenzthiazoline6-sulphonic acid) radical ( $\mathrm{ABTS}^{+}$), and also efficiently inhibited iron-dependent and independent lipid peroxidation and iron chelation assays. In vivo, it inhibited the recruitment of total leukocytes and neutrophil induced by carrageenin, zymosan, glycogen and lipopolysaccharide in the peritoneal cavity of mice. Two mechanisms were detected: 1) T. sinapou effect on leukocyte recruitment depends on nitric oxide since was dose-dependently inhibited by treatment with L-NAME (nitric oxide synthase inhibitor), and 2) the extract also inhibited the production of crucial cytokines for the leukocyte recruitment; tumor necrosis factor $\alpha$ and interleukin-1 $\beta$. Concluding, T. sinapou ethyl acetate extract reduces oxidative stress in vitro, and inflammatory leukocyte recruitment by a mechanism related to inhibition of cytokine production, and in a nitric oxide dependent manner in vivo.
\end{abstract}

Revista Brasileira de Farmacognosia Brazilian Journal of Pharmacognosy 22(3): 587-597, May/Jun. 2012

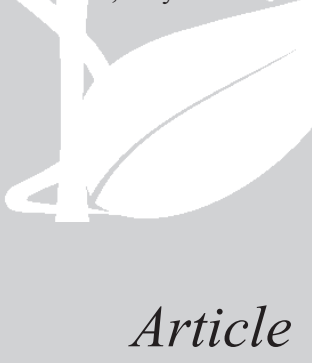

Received 28 May 2011 Accepted 25 Sep 2011 Available online 9 Jan 2012

Keywords: cytokine

inflammation neutrophil nitric oxide oxidative stress Tephrosia sinapou

ISSN 0102-695X http://dx.doi.org/10.1590/S0102695X2012005000006

\section{Introduction}

Although not completely understood, there is a link between oxidative stress and inflammation (Bowie \& O'Neill, 2000; Valério et al., 2009). A conceivable explanation for such relationship is that free radicals activate the transcription factor $\mathrm{NF} \kappa \mathrm{B}$ to induce the production of inflammatory mediators, and are also responsible for tissue lesions by activated phagocytes (Gloire et al., 2006). The opposite route seems also to be truth since inflammatory mediators such as cytokines (e.g. tumor necrosis factor $\alpha[\mathrm{TNF} \alpha]$ ) activate macrophage
NADPH oxidase to produce superoxide anion, which in turn generates hydroxyl radical and peroxynitrite (Bowie \& O'Neill, 2000; Valério et al., 2009; Vicentini et al., 2011). Thus, there is a two way route linking inflammatory mediators and free radicals, and therefore, the interference with this route by antioxidants such as flavonoids explains their anti-inflammatory activity, and suggests their application or even of extracts containing these molecules as anti-inflammatory agents (Andrade et al., 2010; Valério et al., 2009; Vieira et al., 2011; Vicentini et al., 2011).

In this sense, evidence demonstrates that 
flavonoids inhibit inflammation-induced production of free radicals (Casagrande et al., 2006), cytokines (Valério et al., 2009), prostaglandin E (Morikawa et al., 2003), inducible nitric oxide synthase expression and NF $\kappa$ B activation (Vicentini et al., 2011). The modulation of the production of those molecules leads to reduced inflammatory pain (Anjaneyulu \& Chopra, 2003; Anjaneyulu \& Chopra, 2004; Filho et al., 2008; Valério et al., 2009), edema (Valério et al., 2009), and leukocyte recruitment (Souto et al., 2011). Furthermore, there is evidence that inhibition of superoxide anion production reduces neutrophil recruitment (Hattori et al., 2010). Thus, these data support the anti-inflammatory effects of flavonoids and other antioxidants.

An important component of the inflammatory response is the recruitment of leukocytes (e.g. neutrophils) to the inflammatory foci (Favacho et al., 2011; Souto et al., 2011; Valério et al., 2007; Verri at al., 2007; Verri et al., 2010). Many models are used to study leukocyte recruitment, of which the carrageenin stimulus is a widely used model to trigger cytokinedependent inflammation (Neto et al., 2010). In fact, the carrageenin-induced inflammation is a seminal model in the description of the activity and mechanisms of the many of clinically available drugs (Verri et al., 2006). Furthermore, other models are also used such as the glycogen stimulus, which is used to recruit neutrophils in vivo for further in vitro analysis. Zymosan is a stimulus that activates toll-like receptor 2 (Guerrero et al., 2006; Guerrero et al., 2008), and LPS is an agonist of tolllike receptor 4 (Alves-Filho et al., 2010). Activation of these receptors induces cytokine-dependent neutrophil recruitment (Alves-Filho et al., 2010; Guerrero et al., 2006; Guerrero et al., 2008).

Neutrophils are recruited by cytokines such as $\mathrm{TNF} \alpha$ and Interleukin-1 $\beta$ (IL-1 $\beta$ ) and are required to phagocyte and eliminate infectious agents in the inflammatory foci (Lemos et al., 2009; Verri at al., 2007; Verri et al., 2010). These cytokines are crucial in inflammation in a manner that they are virtually involved in every type of inflammation (Lemos et al., 2009; Valério et al., 2007; Verri et al., 2006; Verri et al., 2007; Verri et al., 2008; Verri et al., 2010; Vieira et al., 2009). Moreover, $\mathrm{TNF} \alpha$ and IL- $1 \beta$ are clinically-proved therapeutic targets to diminish inflammation as observed in rheumatoid arthritis with infliximab, etanercept, anakinra and other anti-cytokine antibodies, soluble receptors and receptor antagonists (Verri et al., 2006; Verri et al., 2010).

Neutrophil recruitment is also regulated by other molecules such as nitric oxide (NO), which diminishes the expression of adhesion molecules by endothelial cell, therefore, reducing the rolling, adhesion and transmigration of leukocytes (Tsao et al., 1996). NO also induces the internalization of receptors for chemotatic mediators (Paula-Neto et al., 2011). Nevertheless, excessive inflammation causes tissue damage dependent on metalloproteinases and free radicals produced by neutrophils (Lemos et al., 2009; Verri et al., 2010; PaulaNeto et al., 2011).

The genus Tephrosia involves approximately 400 species distributed in warm regions of both hemispheres (Allen \& Allen, 1981). Species of this genus are known by the presence of compounds with larvicidal, antiviral, anti-cancer and antioxidant activities (Andel, 2000; Andrei et al., 1997; Andrei et al., 2000; Jang et al., 2003; Niassy et al., 2005; Pezzuto et al., 1999; Saleem et al., 2001; Vasconcelos et al., 2009; Yenesew et al., 2006). Preliminary data on the composition analysis of ethyl acetate extract of $T$. sinapou, also known as $T$. toxicaria, revealed the presence of flavonoids, including novel compounds. Therefore, it was investigated in vitro whether $T$. sinapou ethyl acetate extract inhibits oxidative stress and its antioxidant mechanism, and in vivo the effect of the extract on leukocyte recruitment and the role of cytokines and nitric oxide in its mechanisms in mice.

\section{Material and Methods}

\section{Plant material}

Tephrosia sinapou (Buc'hoz) A. Chev., Fabaceae, was cultivated and collected at the Instituto Agronômico de Campinas (IAC), São Paulo, Brazil by S. Myasaka. The identification was performed by A. K. Pastorek in June 2005, and a voucher specimen was deposited at IAC under the number IAC 17211.

\section{Preparation and phytochemical characterization of the extract}

The roots of $T$. sinapou were dried and ground with a knife mill and then the powder was submitted to cool exhaustive extraction with ethyl acetate during ten days with cycles of $48 \mathrm{~h}$. The ethyl acetate extract was exhaustively washed with methanol followed by evaporation. NMR and mass spectral analysis were used for preliminary phytochemical characterization of $T$. sinapou ethyl acetate extract.

\section{Drugs and reagents}

Drugs and reagents were obtained from the following sources: prednisolone from Ouro fino (Cravinhos-SP, Brazil), carrageenin from FMC Corporation (Philadelphia, PA, USA), ELISA kits to determined murine TNF $\alpha$ and IL- $1 \beta$ from eBioscience (San Diego, CA, USA). 2,2-diphenyl-1-picrylhydrazyl $(\mathrm{DPPH})$, thiobarbituric acid (TBA), linoleic acid, 2,2-azino-di-(3-ethylbenzothialozine-sulphonic acid)

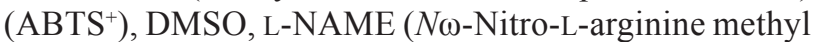


ester hydrochloride), and zymosan from Sigma Chemical Co. (St. Lowis, MO, USA). Bathophenanthroline and quercetin at 95\% purity from Acros (Pittsburgh, PA, USA). Glycogen from Merk (Whitehouse Station, NJ, USA). Lipopolysaccharide from Cayman (Ann Arbor, MI, USA). $\mathrm{KH}_{2} \mathrm{PO}_{4}$, Tween 20 and $\left(\mathrm{NH}_{4}\right)_{2} \mathrm{Fe}\left(\mathrm{SO}_{4}\right)_{2}$ from Labsynth (Diadema-SP, Brazil). $\mathrm{NaOH}$, sodium citrate, $\mathrm{H}_{2} \mathrm{O}_{2}$ and methanol from Biotec (Curitiba-PR, Brazil). $\mathrm{H}_{3} \mathrm{PO}_{4}, \mathrm{KOH}$ and $\mathrm{Cl}_{3} \mathrm{Fe}_{6} \mathrm{H}_{2} \mathrm{O}$ from Vetec (Rio de JaneirRJ, Brazil). $\mathrm{KCl}$ and ethanol from Dinâmica (DiademaSP, Brazil). Propylene glycol, $n$-buthanol from Nuclear (Diadema-SP, Brazil). Potassium persulfate from Neon (São Paulo-SP, Brazil). EDTA from CAAL (São PauloSP, Brazil). $\mathrm{HCl}$ from F. Maia (Cotia-SP, Brazil).

\section{Animals}

The experiments were performed on male Swiss mice (20-25 g) and Wistar rats (200-250 g) from Universidade Estadual de Londrina, Londrina-PR, Brazil housed in standard clear plastic cages for mice or rats (five per cage) with free access to food and water. All testing was performed between 9 am and $5 \mathrm{pm}$ in a temperaturecontrolled room. Animals' care and handling procedures were performed in accordance with National Institute of Health Guide for Care and Use of Laboratory Animals, and with the approval of the Ethics Committee of the Universidade Estadual de Londrina (Of. Circ. CEEA No $147 / 2010$ in November 29, 2010, registered under the number CEEA 80/10, process no 31468.2010.84). All efforts were made to minimize the number of animals used and their suffering.

\section{Antioxidant tests in vitro}

\section{Determination of $\mathrm{DPPH}^{\bullet}$ scavenging activity}

The reduction of $\mathrm{DPPH}^{\bullet}$ radical was determined by the change in the absorbance at $517 \mathrm{~nm}$ (Asuntha et al., 2010; Blois 1958; Casagrande et al., 2007). The T. sinapou ethyl acetate extract was diluted with ethanol/ propilenoglicol solution $(50: 50, \mathrm{v} / \mathrm{v})$. Samples of $T$. sinapou ethyl acetate extract $(25-800 \mu \mathrm{g} / \mathrm{mL})$ were added to reaction medium containing $1 \mathrm{~mL}$ of acetate buffer $0.1 \mathrm{M}(\mathrm{pH} 5.5), 1 \mathrm{~mL}$ of ethanol and $0.5 \mathrm{~mL}$ of ethanolic solution of $\mathrm{DPPH}^{\cdot} 250 \mu \mathrm{M}$. The absorbance values were determined after $20 \mathrm{~min}$ of incubation at room temperature. Samples were analysed in triplicate. The positive control was prepared with sample vehicle, and blank was $1 \mathrm{~mL}$ of acetate buffer $0.1 \mathrm{M}(\mathrm{pH} 5.5)$ and $1.5 \mathrm{~mL}$ of ethanol. The ability of scavenging $\mathrm{DPPH}^{\circ}$ was calculated by the following equation: Equation I: \% of activity $=(1-$ sample absorbance/control absorbance $) \mathrm{x}$ 100 .

\section{$\mathrm{ABTS}^{+} \quad$ [2,2-azino-di-(3-ethylbenzothialozine-}

sulphonic acid)] free radical scavenging assay

The antioxidant capacity by free radical $\mathrm{ABTS}^{+}$ was determined by decrease of absorvance at $730 \mathrm{~nm}$ (Sánchez et al., 2005). The T. sinapou ethyl acetate extract was diluted with dimethylsulfoxide (DMSO). The $\mathrm{ABTS}^{+}$cation was formed with $7 \mathrm{mM} \mathrm{ABTS}^{+}$solution and 2,45 $\mathrm{mM}$ potassium persufate. The mixture was stored in amber flask and room temperature for $16 \mathrm{~h}$ before use. The $\mathrm{ABTS}^{+}$solution was diluted in phosphate buffer $20 \mathrm{mM}(\mathrm{pH} \mathrm{7.4)}$ to obtain an absorvance of 0,7 at 730 $\mathrm{nm}$. Different concentrations of $T$. sinapou ethyl acetate extract $(12.5-250 \mu \mathrm{g} / \mathrm{mL})$ were added in $4 \mathrm{~mL}$ of ABTS+ solution. The absorvance was determined after $6 \mathrm{~min}$ of incubated at room temperature. The positive control was prepared with $100 \mu \mathrm{L}$ of DMSO and $4 \mathrm{~mL}$ ABTS+ solution and blank prepared with phosphate buffer 20 $\mathrm{mM}$ ( $\mathrm{pH}$ 7.4). Samples were analysed in triplicate. The results were expressed as by the equation $\mathrm{I}$.

\section{Iron-independent lipid peroxidation}

In vitro iron-independent lipid peroxidation was determined by the production of lipid hidroperoxides (Lingnert et al., 1979). Firstly, linoleic acid $10 \mathrm{mM}$ was prepared in phosphate buffer $0.1 \mathrm{M}(\mathrm{pH} 6.5)$ containing tween 20, and in $2 \mathrm{~mL}$ of this solution samples of $\mathrm{T}$. sinapou ethyl acette extract $(0.5-160 \mu \mathrm{g} / \mathrm{mL})$ were added. After $8 \mathrm{~h}$ incubation at $37{ }^{\circ} \mathrm{C}$ or without incubation, $0.2 \mathrm{~mL}$ of the linoleic acid emulsion containing or not extract sample were added $2 \mathrm{~mL}$ of methanol and $6 \mathrm{~mL}$ of methanol $60 \%$. The absorbance was determined at $234 \mathrm{~nm}$. The positive control was prepared with sample vehicle (DMSO and ethanol/propilenoglicol [50:50, v/v]) and blank was phosphate buffer $0.1 \mathrm{M}(\mathrm{pH} 6.5)$ with tween 20. All measurements were performed in triplicate. The following equation was used: equação II: \% activity = 1(absA after incubation - absA without incubation)/(absC after incubation - absC without incubation) x 100. AbsA is the absorbance of sample, and absC is the absorbance of the control.

\section{Iron-induced lipid peroxidation}

The ability of the $T$. sinapou ethyl acetate extract to inhibit in vitro lipid peroxidation was evaluated by diminish in the malondialdehide (MDA) formation, which is a secondary product of lipid peroxidation (Buege \& Aust, 1978; Casagrande et al., 2006; Rodrigues et al., 2002). Samples of T. sinapou ethyl acetate extract $(1-160 \mu \mathrm{g} / \mathrm{mL})$ were added to reaction medium containing $1 \mathrm{~mL}$ of reaction medium $(\mathrm{KCl} 130$ $\mathrm{mM}$ and tris- $\mathrm{HCl} 10 \mathrm{mM}, \mathrm{pH} 7.4)$ and $2 \mathrm{mM}$ sodium citrate, mitochondria (1 $\mathrm{mg}$ of protein) and amonical ferrous sulphate $50 \mu \mathrm{M}$. Reaction was incubated at $37^{\circ} \mathrm{C}$ 
for $30 \mathrm{~min}$. After, MDA formation was determined using $1 \mathrm{~mL}$ of thiobarbituric acid (TBA) $1 \%$ prepared in $\mathrm{NaOH}$ $50 \mathrm{mM}, 0.1 \mathrm{~mL}$ of $\mathrm{NaOH} 10 \mathrm{M}$ and $0.5 \mathrm{~mL}$ of $\mathrm{H}_{3} \mathrm{PO}_{4} 20 \%$ followed by incubation for $20 \mathrm{~min}$ at $85^{\circ} \mathrm{C}$. The MDATBA complex was extracted with $2 \mathrm{~mL}$ of $\mathrm{n}$-butanol, centrifuged at $3000 \times \mathrm{g}$ for $15 \mathrm{~min}$ and the absorbance determined at $535 \mathrm{~nm}$. The following controls were used: positive control with sample vehicle (DMSO in ethanol/ propilenoglicol; 50:50, v/v), and negative control without sample and iron. Blank was prepared with the reaction medium without mitochondria. The mitochondria were obtained from male Wistar rats and their isolation was performed by differential centrifugation (Pedersen et al., 1978). The mitochondrial protein content was determined by the biuret reaction (Gornal et al., 1949). All measurements were made in triplicate. The inhibition of iron-dependent lipoperoxidation was calculated by the equation I.

Determination of iron-chelating activity using the bathophenanthroline (BPS) assay

The iron-chelating activity was determined using the bathophenanthroline (BPS) assay (Bolanm \& Ulvik, 1987). Briefly, $\left(\mathrm{NH}_{4}\right)_{2} \mathrm{Fe}\left(\mathrm{SO}_{4}\right)_{2}(50 \mu \mathrm{mol} / \mathrm{L})$, T. sinapou ethyl acetate extract $(0.125-2 \mathrm{mg} / \mathrm{mL}$ diluted in DMSO, and after in a solution of ethanol:propileneglicol; v:v), and BPS $(0.2 \mathrm{mmol} / \mathrm{L})$ were added to $2 \mathrm{~mL}$ of a reaction medium containing $130 \mathrm{mmol} / \mathrm{L}$ de $\mathrm{KCl}$ e $10 \mathrm{mmol} / \mathrm{L}$ tris$\mathrm{HCl} \mathrm{pH}$ 7.4. $\mathrm{Fe}^{2+}$ and $T$. sinapou ethyl acetate extract were left in contact for $15 \mathrm{~min}$ in the reaction medium prior to the addition of BPS, and after that, all reagents were incubated for $15 \mathrm{~min}$ at room temperature. The iron-chelating activity was monitored through the absence of the $\mathrm{Fe}_{2}$ (BPS) complex formation. Measurements were performed at 530 to $700 \mathrm{~nm}$. The positive control was prepared with sample vehicle (DMSO and ethanol/propilenoglicol [50:50, v/v]) and blank was prepared with the reaction medium and iron. All measurements were made in triplicate. The ironchelating activity was calculated by the equation I.

\section{Leukocyte recruitment in mice}

Mice were treated with vehicle $(20 \%$ tween 80 in saline), T. sinapou ethyl acetate extract (10-100 mg/ $\mathrm{kg}$, i.p.) or prednisolone $(4 \mu \mathrm{mol} / \mathrm{kg}$, p.o.) $30 \mathrm{~min}$ before carrageenin $(500 \mathrm{mg} /$ cavity) stimulus. In another set, mice were treated with L-NAME (nitric oxide synthase inhibitor; $10-100 \mathrm{mg} / \mathrm{kg}$, s.c.) $30 \mathrm{~min}$ before treatment with T. sinapou $(100 \mathrm{mg} / \mathrm{kg}$, i.p. $)$. After $30 \mathrm{~min}$ mice received carrageenin $(500 \mu \mathrm{g} /$ mice, i.p. $)$ stimulus. It was also evaluated whether $T$. sinapou inhibits the leukocyte recruitment induced by other stimulus: zymosan (100 $\mu \mathrm{g} /$ mice, i.p. $)$, glycogen $(500 \mu \mathrm{L}$ of $5 \%$ glycogen $)$, and lipopolysaccharide (LPS, $100 \mathrm{ng} /$ mice, i.p.). The negative control of inflammation was saline $(200 \mu \mathrm{L})$ injection. Six hours after the injection of carrageenin, zymosan, glycogen or LPS, mice were terminally anesthetized, and the peritoneal exudates were harvested by introducing 2 $\mathrm{mL}$ of phosphate-buffered saline (PBS) containing $1 \mathrm{mM}$ of EDTA. Total leukocytes counts were performed with a Newbauer chamber, and differential cell counts were carried out on cytocentrifuge slides (Cytospin 3; Shandon Southern Products, Astmoore, UK) stained using the DiffQuik system (Dade Behring). The results were expressed as the number of total leukocytes or neutrophils (Valério et al., 2007).

\section{Cytokine production}

Mice were treated with vehicle $(20 \%$ tween 80 in saline) or T. sinapou ethyl acetate extract $(100 \mathrm{mg} / \mathrm{kg}$, i.p.) $30 \mathrm{~min}$ before carrageenin $(500 \mathrm{mg} /$ cavity $)$ stimulus. Two hours after the injection of carrageenin, mice were terminally anesthetized, and the peritoneal exudates were harvested by introducing $1 \mathrm{~mL}$ of phosphate-buffered saline (PBS) containing $1 \mathrm{mM}$ of EDTA. TNF $\alpha$ and IL-1b levels were determined as described previously (Verri et al., 2007) by an enzyme-linked immunosorbent assay (ELISA) according to manufacture's instructions (eBioscience)

\section{Statistical analysis}

The in vitro concentration of $T$. sinapou ethyl acetate extract necessary to inhibit the oxidative process in 50\% (IC50) was determined by GraphPad Prism ${ }^{\circledR}$ software, version 3.02, using hyperbolic curve (one site binding and two site binding hyperbole). In vivo results are presented as means \pm SEM. of measurements made on 6 animals in each group, and are representative of 2 separated experiments. In vitro results are presented as means \pm SEM of measurements made on triplicate at each concentration, and are representative of 3 separated experiments. The differences between responses were evaluated by one-way ANOVA followed by Tukey's t-test. Statistical differences were considered to be significant at $p<0.05$.

\section{Results}

\section{Phytochemical characterization of the extract}

Preliminary phytochemical analysis of $T$. sinapou ethyl acetate extract by NMR and mass spectral analysis showed the presence of flavonoids: 1) a novel biflavonoid named toxicarine, constituted by glabranine and 5-O-methylnitenin units; 2) flavanone: 7-Omethylglabranine; 3 ) rotenoids: tephrosin, rotenolone, deguelin, 6-oxo-6a,12a-dehydrodeguelin, 6-oxo- 
6a,12a-dehydro- $\alpha$-toxicarol, $\quad 6 a, 12 \mathrm{a}$-dehydrorotenone, rotenonone and villosone; 4) flavanols: tephrowatsin $\mathrm{A}$ and quercetol B. Other identified compounds were: 1) pterocarpan: flamichapparin $\mathrm{B}$; 2) coumarins: 2,3dihydro-p-coumaric acid. Two novel compounds were also identified, a substituted benzaldehyde and a chalcone.

T. sinapou ethyl acetate extract inhibits oxidative stress in vitro

The T. sinapou ethyl acetate extract concentration-dependently scavenged the negatively charged $\mathrm{DPPH}^{\bullet}$ radical (Figure $1 \mathrm{~A}$ ) and the positively charged $\mathrm{ABTS}^{+}$radical (Figure 1B). The IC50 for DPPH $^{*}$ and $\mathrm{ABTS}^{+}$assays were $142 \mu \mathrm{g} / \mathrm{mL}$ and 54.51 $\mu \mathrm{g} / \mathrm{mL}$, respectively (Figure $1 \mathrm{~A}$ and $1 \mathrm{~B}$ ). Control quercetin exhibited IC50 of $1.17 \mu \mathrm{g} / \mathrm{mL}$ and $0.82 \mu \mathrm{g} /$ $\mathrm{mL}$ in the $\mathrm{DPPH}^{\cdot}$ and $\mathrm{ABTS}^{+}$tests, respectively.
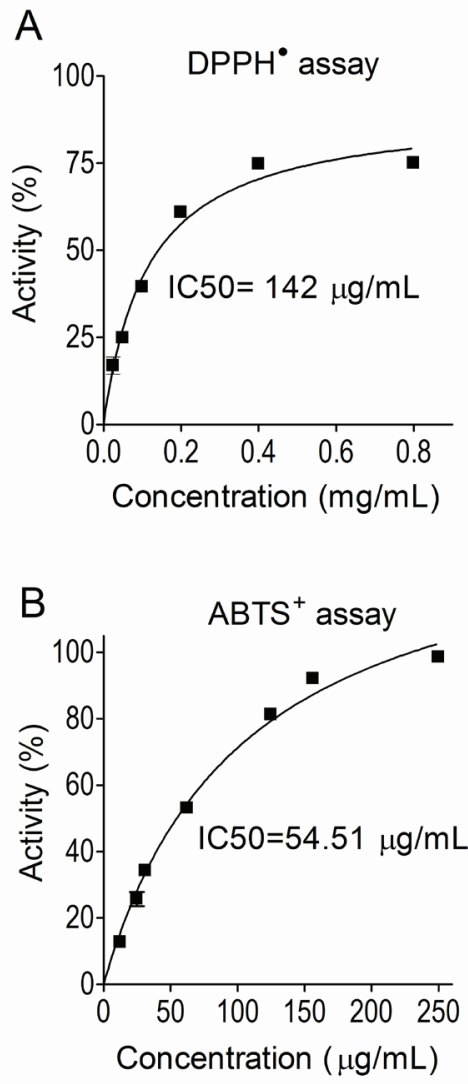

Figure 1. Free radical scavenging activity of Tephrosia sinapou ethyl acetate extract. $T$. sinapou ethyl acetate extract was added at indicated concentration and assayed for scavenging negatively (DPPH•; Panel A) and positively $\left(\mathrm{ABTS}^{+}\right.$, Panel B) assays. Data are present as percentage of inhibition relative to control. Results represent means \pm SEM of triplicate values representative of three separated experiments.
The extract also concentration-dependently inhibited in vitro the lipid peroxidation in the linoleic acid iron-independent assay (Figure 2A), in the iron-dependent peroxidation (Figure 2B) and batophenantroline (Figure 2C), assays with IC50 of $8.53 \mu \mathrm{g} / \mathrm{mL}, 20.10 \mu \mathrm{g} / \mathrm{mL}$ and $1.34 \mathrm{mg} / \mathrm{mL}$, respectively. Control quercetin exhibited with IC50 of $0.51 \mu \mathrm{g} / \mathrm{mL}, 0.34 \mu \mathrm{g} / \mathrm{mL}$ and $4 \mu \mathrm{g} / \mathrm{mL}$ in the linoleic acid iron-independent lipid peroxidation, iron-dependent peroxidation, and iron chelation assays, respectively.
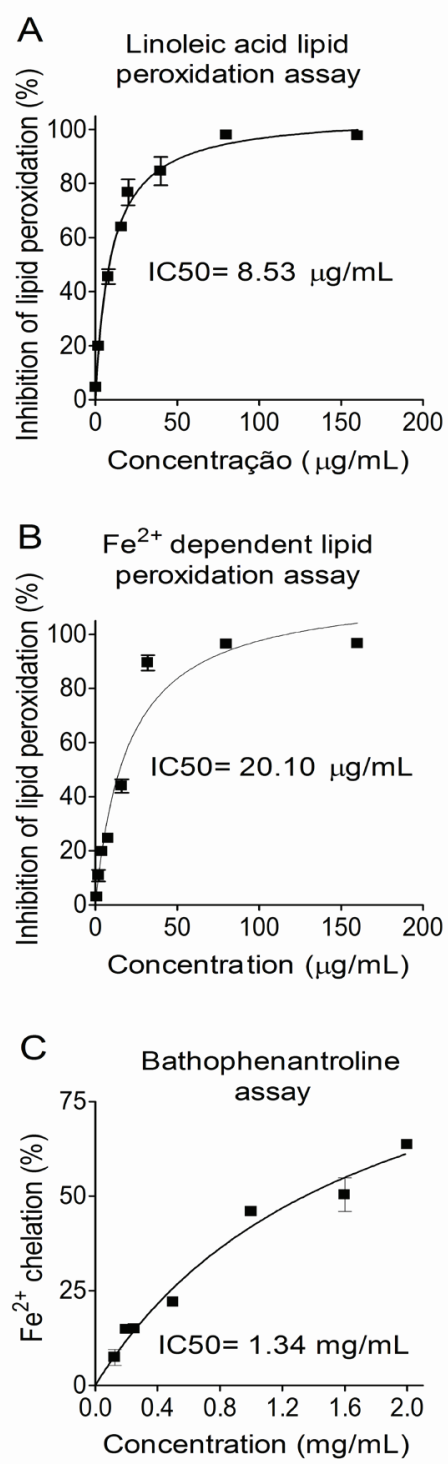

Figure 2. Tephrosia sinapou ethyl acetate extract inhibits lipid peroxidation in vitro at initiation, propagation, termination stages and iron chelating. T. sinapou ethyl acetate extract was added at indicated concentration and assayed for linoleic acid peroxidation ( $\mathrm{Fe}^{2+}$-independent peroxidation; Panel A), $\mathrm{Fe}^{2+}$-dependent peroxidation (Panel B) and bathophenatroline assay to determine $\mathrm{Fe}^{2+}$ chelation (Panel C). Data are present as percentage of inhibition relative to control. Results represent means \pm SEM of triplicate values representative of three separated experiments. 
T. sinapou ethyl acetate extract inhibits in a dosedependent manner the carrageenin-induced leukocyte recruitment in mice.

There was a significant increase of total leukocytes and neutrophils by carrageenin $(500 \mu \mathrm{g} /$ cavity) stimulus, which was dose-dependently inhibited by $T$. sinapou ethyl acetate extract. The dose of $10 \mathrm{mg} /$ $\mathrm{kg}$ of extract did not alter carrageenin-induced cell recruitment. On the other hand, the dose of $30 \mathrm{mg} / \mathrm{kg}$ of extract significantly inhibited the cell recruitment (total leukocytes and neutrophils) induced by carrageenin (Figure 3A and 3B, respectively). The inhibition by 100 $\mathrm{mg} / \mathrm{kg}$ of extract was significant compared to the 10 and
$30 \mathrm{mg} / \mathrm{kg}$ dose of extract regarding total leukocytes and neutrophil recruitment (Figure $3 \mathrm{~A}$ and $3 \mathrm{~B}$ ). Therefore, the dose of $100 \mathrm{mg} / \mathrm{kg}$ of extract was selected for the next experiment. The control drug prednisolone $(4 \mu \mathrm{mol} / \mathrm{kg}$, corticosteroid) inhibited carrageenin-induced leukocyte and neutrophil recruitment (Figure $3 \mathrm{~A}$ and $3 \mathrm{~B}$ ).

T. sinapou ethyl acetate extract inhibits zymosan-, glycogen-, and LPS (lipopolysaccharide)-induced leukocyte recruitment in mice.

Zymosan (100 $\mu \mathrm{g} /$ cavity), glycogen $(500 \mu \mathrm{L}$ of 5\% solution/cavity) and LPS (100 ng/cavity) induced significant total leukocyte and neutrophil recruitment to the peritoneal cavity, which was inhibited by T. sinapou ethyl acetate extract (Figure 4A and 4B).
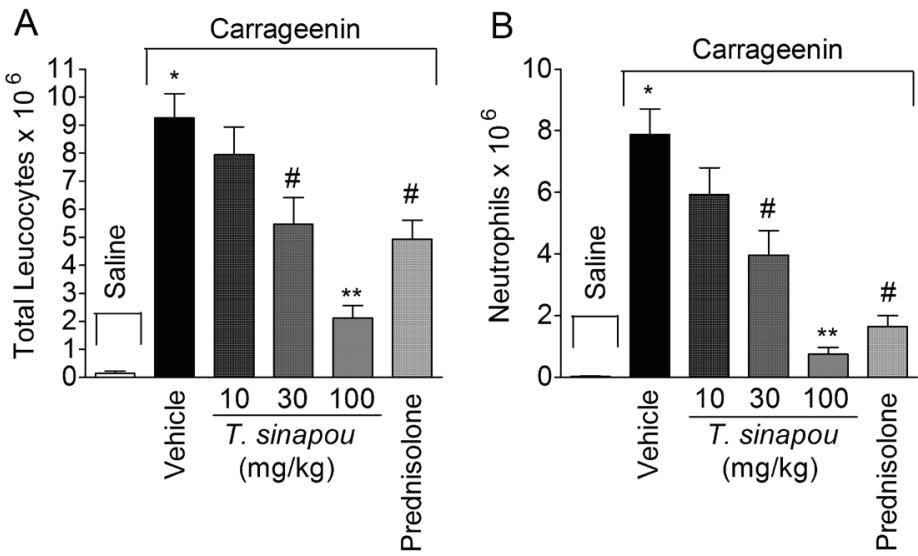

Figure 3. Tephrosia sinapou ethyl acetate extract inhibits in a dose-dependent manner the carrageenın-induced leukocyte recruitment. Mice were treated with vehicle $(20 \%$ tween 80 in saline) or ethyl acetate extract of T. sinapou $(10-100 \mathrm{mg} / \mathrm{kg}$, intraperitoneal route) $30 \mathrm{~min}$ before carrageenin $(500 \mu \mathrm{g} /$ cavity) stimulus. The negative control of inflammation was saline $(200 \mu \mathrm{L})$ injection, and control drug was prednisolone $(4 \mu \mathrm{mol} / \mathrm{kg}, 30 \mathrm{~min}$ before carrageenin). Total leukocytes (Panel A), and neutrophils (Panel B) were determined $6 \mathrm{~h}$ after stimulus injection. Bars represent means \pm SEM of six mice per group, and are representative of two separated experiments. ${ }^{*} p<0.05$ compared to saline group, ${ }^{*} p<0.05$ compared to vehicle + carrageenin group, and $* * p<0.05$ compared to the doses of 10 and $30 \mathrm{mg} / \mathrm{kg}$ of extract. One-way ANOVA followed by Tukey's t-test.
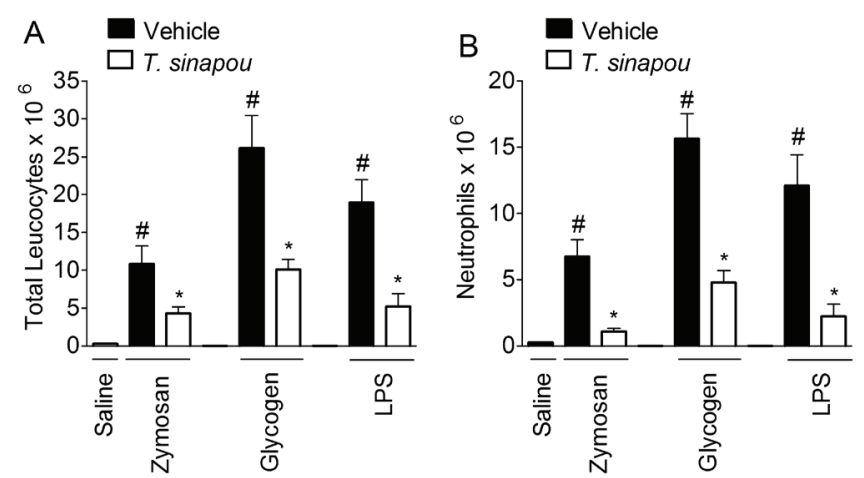

Figure 4. Tephrosia sinapou ethyl acetate extract inhibits zymosan-, glycogen-, and LPS-induced leukocyte recruitment. Mice were treated with vehicle ( $20 \%$ tween 80 in saline) or ethyl acetate extract of T. sinapou $(100 \mathrm{mg} / \mathrm{kg}$, i.p.) 30 min before zymosan $(100 \mu \mathrm{g} /$ cavity), glycogen $(500 \mu \mathrm{L}$ of $5 \%$ solution/cavity) or LPS (100 ng/cavity) stimulus. The negative control of inflammation was saline injection. Total leukocytes (Panel A), and neutrophils (Panel B) were determined $6 \mathrm{~h}$ after stimulus injection. Bars represent means \pm SEM of six mice per group, and are representative of two separated experiments. ${ }^{*} p<0.05$ compared to saline group, ${ }^{*} p<0.05$ compared to vehicle+stimulus group. One-way ANOVA followed by Tukey's t-test. 
T. sinapou ethyl acetate extract inhibition of carrageenininduced inflammation depends on nitric oxide.

The subcutaneous treatment with L-NAME dose-dependently prevented $T$. sinapou antiinflammatory inhibition of total leukocytes and neutrophil recruitment induced by carrageenin $(500 \mu \mathrm{g} /$ cavity) (Figure 5A and 5B). The doses of 10 and $30 \mathrm{mg} /$ $\mathrm{kg}$ of L-NAME presented no significant effect, but the dose of $30 \mathrm{mg} / \mathrm{kg}$ showed a tendency of prevention of T. sinapou activity. The dose of $100 \mathrm{mg} / \mathrm{kg}$ of L-NAME significantly prevented $T$. sinapou inhibition of total leukocytes and neutrophil recruitment compared to $\mathrm{T}$. sinapou extract control and also to L-NAME $10 \mathrm{mg} / \mathrm{kg}$ group (Figure 5).
T. sinapou ethyl acetate extract inhibited carrageenininduced cytokine production.

There was a significant increase of TNF $\alpha$ (Figure 6A) and IL-1 $\beta$ (Figure 6B) production in the peritoneal exudates of mice comparing saline control group and carrageenin $(500 \mu \mathrm{g} / \mathrm{cavity})$ stimulus $2 \mathrm{~h}$ after injection. On the other hand, the treatment with $T$. sinapou extract $(100 \mathrm{mg} / \mathrm{kg})$ significantly inhibited the production of TNF $\alpha$ (Figure 6A) and IL-1 $\beta$ (Figure 6B). It is noteworthy to mention that the carrageenin-induced production of TNF $\alpha$ and IL-1 $\beta$ was almost abolished by T. sinapou extract.
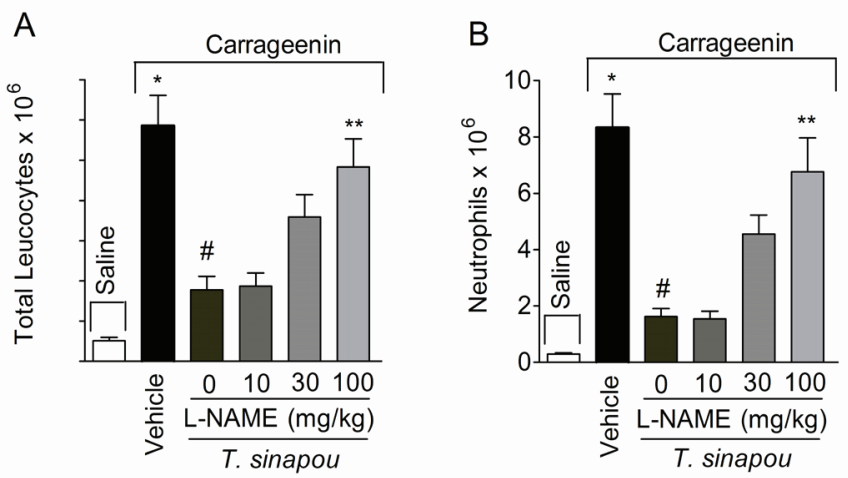

Figure 5. Tephrosia sinapou ethyl acetate extract inhibition of leukocyte recruitment depends on nitric oxide. Mice were treated with L-NAME (10-100 mg/kg, s.c., nitric oxide synthase inhibitor) $30 \mathrm{~min}$ before $T$. sinapou ethyl acetate extract $(100 \mathrm{mg} / \mathrm{kg}$, intraperitoneal route) treatment. After additional $30 \mathrm{~min}$, mice received i.p. stimulus with carrageenin $(500 \mu \mathrm{g} / \mathrm{cavity})$. The negative control of inflammation was saline $(200 \mu \mathrm{L}$ ) injection. Total leukocytes (Panel A), and neutrophils (Panel B) were determined $6 \mathrm{~h}$ after stimulus injection. Bars represent means \pm SEM of six mice per group, and are representative of two separated experiments. ${ }^{*} p<0.05$ compared to saline group, ${ }^{*} p<0.05$ compared to vehicle+carrageenin group, and ${ }^{*} p<0.05$ compared to extract and lower dose of L-NAME tested. One-way ANOVA followed by Tukey's t-test.
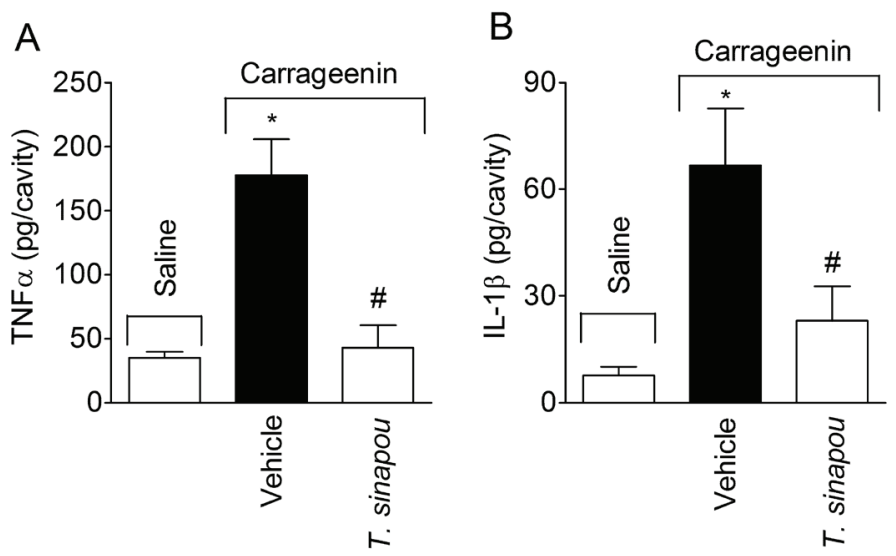

Figure 6. Tephrosia sinapou ethyl acetate extract inhibits carrageenin-induced cytokine production. Mice were treated with vehicle ( $20 \%$ tween 80 in saline) or ethyl acetate extract of $T$. sinapou (100 mg/kg, intraperitoneal route) $30 \mathrm{~min}$ before carrageenin $(500 \mu \mathrm{g} / \mathrm{cavity})$ stimulus. The negative control of inflammation was saline $(200 \mu \mathrm{L})$ injection. The production of the cytokines TNF $\alpha$ (Panel A) and IL-1 $\beta$ (Panel B) were determined $2 \mathrm{~h}$ after stimulus injection. Bars represent mean \pm SEM of five mice per group, and are representative of two separated experiments. ${ }^{*} p<0.05$ compared to saline group, and ${ }^{\#} p<0.05$ compared to vehicle+carrageenin group. One-way ANOVA followed by Tukey's t-test. 


\section{Discussion}

In the present study, it was demonstrated that the ethyl acetate extract of Tephrosia sinapou (Buc'hoz) A. Chev., Fabaceae, inhibits inflammatory total leukocytes and neutrophil recruitment induced by a variety of inflammatory stimuli corroborating its wide applicability. Furthermore, the mechanisms of $T$. sinapou involve the inhibition of leukocyte recruitment in a nitric oxide (NO)dependent manner and also by inhibition of carrageenininduced production of the chemotatic cytokines $\mathrm{TNF} \alpha$ and IL-1 $\beta$.

There is evidence of pharmacological activity of extracts obtained from plants of Tephosia genus including toxic and lavicidal effects (Arriaga et al., 2009a; Lapointe et al., 2003), antifungal (Vijayan et al., 2008), anti-Helicobacter pylori (Chinniah et al., 2009), wound healing potential (Lodhi et al., 2006), hepatoprotective against thioacetamide-induced hepatotoxicity (Khatri et al., 2009), antihyperglycemic and antihyperlipidemic in streptozotocin induced diabetic rats (Pavana et al., 2007), alleviates phorbol ester-induced tumor promotion response in murine skin (Saleem et al., 2001), ameliorates $\mathrm{N}$-diethylnitrosamine and potassium bromate-mediated renal oxidative stress and toxicity in rats (Khan et al., 2001), reduction in the severity of lithium-pilocarpine induced status epilepticus (Asuntha et al., 2010) and a flavonoidal fraction of $T$. purpurea inhibits sheep red blood cells-induced delayed-type hypersensitivity reactions (Damre et al., 2003). Thus, there are some pharmacological studies on the Tephosia genus activities. One report demonstrated the cancer chemopreventive effect of flavonoids from T. sinapou (Jang et al., 2003).

Preliminary results detected the presence of flavonoids including novel compounds in $T$. sinapou ethyl acetate extract. Flavonoids are phenolic antioxidant compounds, and this activity explains, at least in part, their other effects on modulation of inflammation. It is consensus that there is a relation between oxidative stress and the production of inflammatory mediators including cytokines. In fact, oxidative stress activates the transcription factor $\mathrm{NF} \kappa \mathrm{B}$ to induce cytokine production (Vicentini et al., 2011). The present data demonstrates that $T$. sinapou extract inhibited oxidative stress and its antioxidant mechanisms. T. sinapou components act as free radical scavengers of negatively and positively charged free radicals, $\mathrm{DPPH}^{\cdot}$ and $\mathrm{ABTS}^{+}$, respectively. Furthermore, T. sinapou also inhibited in vitro the ironindependent lipid peroxidation as observed in the linoleic acid assay, which is a step in the initiation of lipid peroxidation as well as iron-dependent lipid peroxidation that involves propagation and termination events of lipid peroxidation as observed in the malondialdehyde (MDA, product of lipid peroxidation) and iron chelating assays. Herein, we provide evidence that $T$. sinapou ethyl acetate extract dose-dependently inhibited total leukocytes and neutrophil recruitment to the inflammatory foci in the classic model of carrageenin-induced peritonitis. Furthermore, $T$. sinapou also inhibited the recruitment of leukocytes induced by zymosan, glycogen and LPS. Therefore, T. sinapou inhibited the leukocyte recruitment induced by a variety of stimuli supporting its possible usefulness.

Mechanistically, T. sinapou inhibition of leukocyte recruitment was dependent on NO since was prevented by L-NAME treatment, a NO synthase (NOS) inhibitor. NO is a gas with multiple functions, including the reduction of adhesion molecules expression by endothelial cell during inflammatory conditions (Tsao et al., 1996) and internalization of chemotatic receptors in neutrophil (Paula -Neto et al., 2011).

Cytokines are also important mediators in inflammation responsible for leukocyte recruitment. $T$. sinapou almost abolished carrageenin-induced TNF $\alpha$ and IL-1 $\beta$ production in the peritoneal exudates. Thus, the $T$. sinapou extract inhibited the recruitment of leukocytes by reducing the production of those clinically relevant pro-inflammatory cytokines, TNF $\alpha$ and IL-1 $\beta$.

At least in part, the pharmacological property of T. sinapou extract to inhibit inflammation and oxidative stress might be related to its flavonoidal content as shown for other plants of Tephrosia genus (Arriaga et al., 2009b; Hegazy et al., 2009; Khalivulla et al., 2008; Reddy et al., 2009) since flavonoids inhibit oxidative stress, inflammation and/or cytokine production, and present NO-dependent effects (Casagrande et al., 2006; Filho et al., 2008; Georgetti et al., 2008; Souto et al., 2011; Valério et al., 2009; Vicentini et al., 2011).

This study provides pre-clinical evidence of anti-inflammatory activity of an extract of Tephrosia sinapou, and demonstrates that the antiinflammatory mechanisms of $T$. sinapou ethyl acetate extract are related to inhibition of pro-inflammatory cytokine (TNF $\alpha$ and IL-1 $\beta$ ) production and NOdependent inhibition of leukocyte recruitment in mice. Furthermore, in vitro data demonstrated that the extract inhibits of oxidative stress by scavenging free radicals, iron chelating activity and inhibition of irondependent and iron-independent lipoperoxidation. The extension of these antioxidant mechanisms remains to be determined in vivo. Considering that preliminary data detected novel flavonoids in $T$. sinapou extract, we speculate that isolated compounds from Tephrosia genus plants, including $T$. sinapou, are conceivable sources of novel anti-inflammatory compounds worthy of further investigation.

\section{Acknowledgments}

We appreciated the technical support of Jesus 
A. Vargas and Pedro S. R. Dionísio Filho. This work was supported by grants from Fundação Araucária, Conselho Nacional de Pesquisa, and Coordenadoria de aperfeiçoamento de Pessoal de Nível Superior, Brazil.

\section{References}

Allen O, Allen EK 1981. The Leguminosae. Madison WI: The University of Wisconsin Press.

Alves-Filho JC, Sônego F, Souto FO, Freitas A, Verri WA Jr, Auxiliadora-Martins M, Basile-Filho A, McKenzie NA, Xu D, Cunha FQ, Liew FY 2010. Interleukin-33 attenuates sepsis by enhancing neutrophil influx to the site of infection. Nat Med 16: 708-712.

Andel TV 2000. The diverse uses of fish-poison plants in Northwest Guyana. Econ Botany 54: 500-512.

Andrade MA, Oliveira JPR, Santos ALLM, Franco CRP, Antoniolli AR, Estevam CS, Thomazzi SM 2010. Preliminary study on the anti-inflammatory and antioxidant activities of the leave extract of Hyptis fruticosa Salzm. ex Benth., Lamiaceae. Rev Bras Farmacogn 20: 262-968.

Andrei CC, Vieira PC, Fernandes JB, Silva MFGF, Fo ER 1997. Dimethylchromene rotenoids from Tephrosia candida. Phytochemistry 46: 1081-1085.

Andrei CC, Ferreira DT, Faccione M, Moraes LAB, Carvalho MG, Filho RB 2000. C-prenylflavonoids from roots of Tephrosia tunicata. Phytochemistry 55: 799-804.

Anjaneyulu M, Chopra K 2003. Quercetin, a biflavonoid, attenuates thermal hyperalgesia in a mouse model of diabetic neuropathic pain. Prog Neuropsychopharmacol Biol Psychiat 27: 10011005.

Anjaneyulu M, Chopra K 2004. Quercetin attenuates thermal hyperalgesia and cold allodynia in STZ-induced diabetic rats. Indian J Exp Biol 42: 766-769.

Arriaga AM, Lima JQ, Vasconcelos JN, de Oliveira MC, Lemos TL, Fonseca AM, Malcher GT, Santiago GM, Mafezoli J, Braz-Filho R 2009a. Antioxidant and larvicidal activities of Tephrosia egregia Sandw against Aedes aegypti. Nat Prod Commun 4: 529-530.

Arriaga AM, Lima JQ, Vasconcelos JN, de Oliveira MC, Andrade-Neto M, Santiago GM, Uchoa DE, Malcher GT, Mafezoli J, Braz-Filho R 2009b. Unequivocal assignments of flavonoids from Tephrosia sp. (Fabaceae). Magn Reson Chem 47: 537-540.

Asuntha G, Prasannaraju Y, Sujatha D, Prasad KVSRG 2010. Assessment of effect of ethanolic extract of Tephrosia purpurea (L.) Pers., Fabaceae, activity on lithiumpilocarpine induced Status epilepticus and oxidative stress in Wistar rats. Rev Bras Farmacogn 20: $767-$ 772.

Blois MS 1958. Antioxidant determination by the use of a stable free radical. Nature 181: 1199-1200.

Bolanm BJ, Ulvik RJ 1987. Release of iron from ferritin by xanthine oxidase. Role of the superoxide radical. Biochem J 243: 55-59.

Bowie A, O'Neill LA 2000. Oxidative stress and nuclear factorkappaB activation: a reassessment of the evidence in the light of recent discoveries. Biochem Pharmacol 59: 13-23.

Buege JA, Aust SD 1978. Microsomal lipid peroxidation. Method Enzymol 52: 302-310.

Casagrande R, Georgetti SR, Verri WA Jr, Borin MF, Lopez RFV, Fonseca MJV 2007. In vitro evaluation of quercetin cutaneous absorption from topical formulations and its functional stability by antioxidant activity. Int $J$ Pharm 328: 183-190.

Casagrande R, Georgetti SR, Verri WA Jr, Dorta DJ, Santos AC, Fonseca MJV 2006. Protective effect of topical formulations containing quercetin against UVB-induced oxidative stress in hairless mice. $J$ Photoch Photobio $B$ 84: 21-27.

Chinniah A, Mohapatra S, Goswami S, Mahapatra A, Kar SK, Mallavadhani UV, Das PK 2009. On the potential of Tephrosia purpurea as anti-Helicobacter pylori agent. J Ethnopharmacol 124: 642-645.

Damre AS, Gokhale AB, Phadke AS, Kulkarni KR, Saraf MN 2003. Studies on the immunomodulatory activity of flavonoidal fraction of Tephrosia purpurea. Fitoterapia 74: 257-261.

Favacho HAS, Oliveira BR, Santos KC, Medeiros BJL, Sousa PJC, Perazzo FF, Carvalho JCT 2011. Anti-inflammatory and antinociceptive activities of Euterpe oleracea oil. Rev Bras Farmacogn 21: 105-114.

Filho AW, Filho VC, Olinger L, Souza MM 2008. Quercetin: further investigation of its antinociceptive properties and mechanisms of action. Arch Pharm Res 31: 713721.

Georgetti SR, Casagrande R, Verri WA Jr; Lopez RFV, Fonseca MJV 2008. Evaluation of in vivo efficacy of topical formulations containing soybean extract. Int $J$ Pharm 352: 189-196.

Gloire G, Legrand-Poels, S, Piette J 2006. NF-kappaB activation by reactive oxygen species: fifteen years later. Biochem Pharmacol 72: 1493-1505.

Gornal AG, Bardill CJ, David MM 1949. Determination of serum proteins by means of the biuret reaction. $J$ Biol Chem 177: 751-766.

Guerrero AT, Verri WA Jr, Cunha TM, Silva TA, Rocha FA, Ferreira SH, Cunha FQ, Parada CA 2006. Hypernociception elicited by tibio-tarsal joint flexion in mice: a novel experimental arthritis model for pharmacological screening. Pharmacol Biochem Behav 84: 244-251.

Guerrero AT, Verri WA Jr, Cunha TM, Silva TA, Schivo IR, DalSecco D, Canetti C, Rocha FA, Parada CA, Cunha FQ, Ferreira SH 2008. Involvement of LTB4 in zymosaninduced joint nociception in mice: participation of neutrophils and PGE2. J Leukoc Biol 83: 122-130. 
Hattoria H, Subramaniana KK, Sakaia J, Jia Y, Li Y, Porter TF, Loison F, Sarraj B, Kasorn A, Jo H, Blanchard C, Zirkle D, McDonald D, Pai SY, Serhan CN, Luo HR 2010. Small molecule screen identifies reactive oxygen species as key regulators of neutrophil chemotaxis. Proc Natl Acad Sci USA 107: 3546-3551.

Hegazy ME, Abd el-Razek MH, Nagashima F, Asakawa Y, Paré PW 2009. Rare prenylated flavonoids from Tephrosia purpurea. Phytochemistry 70: 1474-1477.

Jang DS, Park EJ, Kang YH, Hawthorne ME, Vigo JS, Graham JG, Cabieses F, Fong HH, Mehta RG, Pezzuto JM, Kinghorn AD 2003. Potential cancer chemopreventive flavonoids from the stems of Tephrosia toxicaria. J Nat Prod 66: 1166-1170.

Khalivulla SI, Reddy BA, Gunasekar D, Blond A, Bodo B, Murthy MM, Rao TP 2008. A new di-O-prenylated isoflavone from Tephrosia tinctoria. J Asian Nat Prod Res 10: 953-955.

Khan N, Sharma S, Alam A, Saleem M, Sultana S 2001. Tephrosia purpurea ameliorates $N$-diethylnitrosamine and potassium bromate-mediated renal oxidative stress and toxicity in Wistar rats. Pharmacol Toxicol 88: 294299.

Khatri A, Garg A, Agrawal SS 2009. Evaluation of hepatoprotective activity of aerial parts of Tephrosia purpurea L. and stem bark of Tecomella undulata. J Ethnopharmacol 122: 1-5.

Lapointe SL, McKenzie CL, Hunter WB 2003. Toxicity and repellency of Tephrosia candida to larval and adult Diaprepes root weevil (Coleoptera: Curculionidae). $J$ Econ Entomol 96: 811-816.

Lemos HP, Grespan R, Vieira SM, Cunha TM, Verri WA Jr, Fernandes KSS, Souto FO, McInnes IB, Ferreira SH, Liew FY, Cunha FQ 2009. Prostaglandin mediates IL23/IL-17-induced neutrophil migration in inflammation by inhibiting IL-12 and IFN production. Proc Natl Acad Sci USA 106: 5954-5959.

Lingnert H, Valentin K, Erickson CE 1979. Measurement of antioxidative effect in model system. $J$ Food Process Pres 3: 87-104.

Lodhi S, Pawar RS, Jain AP, Singhai AK 2006. Wound healing potential of Tephrosia purpurea (Linn.) Pers. in rats. $J$ Ethnopharmacol 108: 204-210.

Morikawa K, Nonaka M, Narahara M, Torri I, Kawaguchi K, Yoshikawa T, Kumazawa Y, Morikawa S 2003. Inhibitory effect of quercetin on carrageenan-induced inflammation in rats. Life Sci 74: 709-721.

Neto VA, Bomfim RR, Oliveira VOB, Passos AMPR, Oliveira JPR, Lima CA, Mendes SS, Estevam CS, Thomazzi SM 2010 Therapeutic benefits of Sideroxylon obtusifolium (Humb. Ex Roem. \& Schult.) T.D. Penn., Sapotaceae, in experimental models of pain and inflammation. Rev Bras Farmacogn 20: 933-938.

Niassy B, Lobstein A, Um BH, Anton R, Koné MEK 2005. Flavonoids from Tephrosia deflexa and T. albifoliolis.
Biochem Syst Ecol 33: 309-312.

Paula-Neto HA, Alves-Filho JC, Souto FO, Spiller F, Amêndola RS, Freitas A, Cunha FQ, Barja-Fidalgo C 2011. Inhibition of guanylyl cyclase restores neutrophil migration and maintains bactericidal activity increasing survival in sepsis. Shock 35: 1727.

Pavana P, Manoharan S, Renju GL, Sethupathy S 2007. Antihyperglycemic and antihyperlipidemic effects of Tephrosia purpurea leaf extract in streptozotocin induced diabetic rats. J Environ Biol 28: 833-837.

Pedersen PL, Greenawalt JW, Reynafarje B, Hullihen J, Decker GL, Soper JW, Bustamente E 1978. Preparation and characterization of mitochondria and submitochondrial particles of rat liver and liver-derived tissues. Methods Cell Biol 20: 411-481.

Pezzuto JM, Song LL, Lee SK, Shamon LA, Mata-Grenwood E, Jang M, Jeong HJ, Pisha E, Mehta RG, Kinghorn AD 1999. Bioassay methods useful for activity- guided isolation of natural product cancer chemopreventive agents. In Hostettmann K, Gupta MP, Marston A (org.) Chemistry, biological and pharmacological properties of medicinal plants from the Americas. Amsterdam: Harwood Academic, p. 81-110.

Reddy RV, Khalivulla SI, Reddy BA, Reddy MV, Gunasekar D, Deville A, Bodo B 2009. Flavonoids from Tephrosia calophylla. Nat Prod Commun 4: 59-62.

Rodrigues T, Santos AC, Pigoso AA, Mingatto FE, Uyemura as, Curti C 2002. Thioridazine interacts with the membrane of mitochondria acquiring antioxidant activity toward apoptosis-potentially implicated mechanisms. $\mathrm{Br} J$ Pharmacol 136: 136-142.

Saleem M, Ahmed Su, Alam A, Sultana S 2001. Tephrosia purpurea alleviates phorbol ester-induced tumor promotion response in murine skin. Pharmacol Res 43: 135-144.

Sánchez-Gonzalez I, Jiménez-Escrig A, Saura-Calixto F 2005. In vitro antioxidant activity of coffees brewed using different procedures (italian, espresso and filter). Food Chem 90: 133-139.

Souto FO, Zarpelon AC, Ferrari LS, Fattori V, Casagrande R, Fonseca MJV, Cunha TM, Ferreira SH, Cunha FQ, Verri, WA Jr 2011. Quercetin reduces neutrophil recruitment induced by CXCL8, LTB4, and fMLP: inhibition of actin polymerization. $J$ Nat Prod 74: 113-118.

Tsao PS, Buitrago R, Chan JR, Cooke JP 1996. Fluid flow inhibits endothelial adhesiveness. Nitric oxide and transcriptional regulation of VCAM-1. Circulation 94: 1682-1689.

Valério DA, Cunha TM, Arakawa NS, Lemos HP, Da Costa FB, Parada CA, Ferreira SH, Cunha FQ, Verri WA Jr 2007. Anti-inflammatory and analgesic effects of the sesquiterpene lactone budlein $\mathrm{A}$ in mice: inhibition of cytokine production-dependent mechanism. Eur $J$ Pharmacol 562: 155-163. 
Valério DA, Georgetti SR, Magro DA, Casagrande R, Cunha TM, Vicentini FT, Vieira SM, Fonseca MJ, Ferreira SH, Cunha FQ, Verri WA Jr 2009. Quercetin reduces inflammatory pain: inhibition of oxidative stress and cytokine production. J Nat Prod 72: 1975-1979.

Vasconcelos JN, Lima JQ, Lemos TLG, Oliveira MCF, Almeida MMB, Andrade Neto M, Mafezoli J, Arriaga AMC 2009. Estudo químico e biológico de Tephrosia toxicaria Pers. Quim Nova 15: 1-5.

Verri WA Jr, Cunha TM, Parada CA, Poole S, Cunha FQ, Ferreira SH 2006. Hypernociceptive role of cytokines and chemokines: target for analgesic drug development? Pharmacol Ther 112: 116-138.

Verri WA Jr, Cunha TM, Ferreira SH, Leung BP, McInnes IB, Fraser A, Liew FY, Cunha FQ 2007. Role of IL-15 in antigen-induced neutrophil migration by triggering IL18 production. Eur J Immunol 37: 3373-3380.

Verri WA Jr, Guerrero AT, Fukada SY, Valério DA, Cunha TM, Xu D, Ferreira SH, Liew FY, Cunha FQ 2008. IL-33 mediates antigen-induced cutaneous and articular hypernociception in mice. Proc Natl Acad Sci USA 105: 2723-2728.

Verri WA Jr, Souto FO, Vieira SM, Almeida SCL, Fukada SY, Xu D, Alves-Filho JC, Cunha TM, Guerrero ATG, MattosGuimaraes RB, Oliveira FR, Teixeira MM, Silva JS, McInnes IB, Ferreira SH, Louzada-Junior P, Liew FY, Cunha FQ 2010. IL-33 induces neutrophil migration in rheumatoid arthritis and is a target of anti-TNF therapy. Ann Rheum Dis 69: 1697-1703.

Vicentini FTMC, He T, Shao Y, Fonseca MJV, Verri WA Jr, Fisher GJ, Xu Y 2011. Quercetin inhibits UV irradiationinduced inflammatory cytokine production in primary human keratinocytes by suppressing NF-kB pathway. $J$ Dermatol Sci 61: 162-168.

Vieira SM, Lemos HP, Grespan R, Napimoga MH, Dal-Secco D, Freitas A, Cunha TM, Verri WA Jr, Souza-Junior DA, Jamur MC, Fernandes KS, Oliver C, Silva JS, Teixeira
MM, Cunha FQ 2009. A crucial role for TNF- $\alpha$ in mediating neutrophil influx induced by endogenously generated or exogenous chemokines, KC/CXCL1 and LIX/CXCL5. Br J Pharmacol 158: 779-789.

Vieira TO, Seifriz I, Charão CCT, Oliveira SQ, CreczynskiPasa TB 2011 Antioxidant effects of crude extracts from Baccharis species: inhibition of myeloperoxidase activity, protection against lipid peroxidation, and action as oxidative species scavenger. Rev Bras Farmacogn 21: 601-607.

Vijayan S, Guruprasad L, Kirti PB 2008. Prokaryotic expression of a constitutively expressed Tephrosia villosa defensin and its potent antifungal activity. Appl Microbiol Biotechnol 80: 1023-1032.

Yenesew A, Kiplagat JT, Derese S, Midiwo JO, Kabaru JM, Heydenreich M, Peter MG 2006. Two unusual rotenoid derivatives, $7 \alpha$-O-methyl-12 $\alpha$-hydroxydeguelol and spiro-13-homo-13-oxaelliptone, from the seeds of Derris trifoliate. Phytochemistry 67: 988-991.

\section{*Correspondence}

Rubia Casagrande

Departamento de Ciências Farmacêuticas, Hospital Universitário, Universidade Estadual de Londrina

Av. Robert Koch, 60, 86038-350 Londrina-PR, Brazil

rubiacasa@uel.br

Tel: +554333712475

Fax: + 554333712475

Waldiceu A. Verri Jr

Departamento de Patologia, Universidade Estadual de Londrina

Rod. Celso Garcia Cid km 480 PR445, 86051-990, Caixa Postal 6001, Londrina-PR, Brazil

waverri@uel.br

Tel: + 554333714979

Fax: + 554333714387 